Journal of Agriculture and Social Research (JASR) Vol. 8, No. 2, 2008

\title{
ECONOMIC ANALYSIS OF THE EFFECT OF ORGANO-MINERAL FERTILIZER ON TOMATO YIELD COMPONENT IN HUMID FOREST ZONE OF NIGERIA
}

\author{
D. I. AKANNI* AND BIFARIN J.O** \\ *Department of Agronomy, Federal College of Agriculture, Akure. \\ **Department of Agricultural Extension and Management. \\ Federal College of Agriculture, Akure, Nigeria.
}

\begin{abstract}
Field experiment were carried out during 2003/2004 cropping seasons (early and late), with tomatoes (Lycopersicum esculentum mill) at the Federal College of Agriculture and Edu village in Akure to evaluate the economic viability of different types and levels of manure. The first experiment compared $100 \mathrm{Kg} \mathrm{ha}^{-1} \mathrm{~N}-\mathrm{P}-\mathrm{K} 20-10-15$, and $25 \mathrm{t} \mathrm{ha}$ each of the cattle, goat, pig and poultry, where poultry and goat manure had the best impact. The second experiment compared five levels of poultry and goat manures (0,10, 25, 40 and 50 th $^{-1}$ ) separately. Result showed that late crop was more profitable than early crop because of excessive moisture and FECA site better than Edu because the former was better in terms of soil structure before the application of manure. Result further showed that, as higher level of manure was applied, yield increased up to $25 \mathrm{t} \mathrm{ha} \mathrm{h}^{-1}$. It was concluded that poultry and goat manure applied separately were generally more profitable at $25 \mathrm{tha}^{-1}$.
\end{abstract}

Key words: Economic analysis, organo-mineral fertilizer, tomato yield

\section{INTRODUCTION}

Tomato is one of the most important vegetable crops in Nigeria. Over 95\% of land area in southwest Nigeria has low to medium levels of phosphorus (P) to support tomato production. Tomato yields are as much as 13.5 and $21 \mathrm{t} \mathrm{ha}^{-1}$ in tropical Africa and other part of the world respectively but in Nigeria, the yield is as low as $10 \mathrm{tha}^{-1}$ (F.A.O, 1993), the demands of tomatoes for $\mathrm{N}, \mathrm{P}$ and $\mathrm{K}$ are high and studies in south west Nigeria showed that tomato yield was significantly increased by application and availability of $\mathrm{N}$, $\mathrm{P}, \mathrm{K}, \mathrm{Ca}$ and $\mathrm{Mg}$ fertilizers (Adekiya and Ojeniyi, 2002). Studies on the economic analysis on the application of inorganic and organic fertilizer to horticultural crops such as tomato are not common in literature. This is partly because most farmers generally cultivate horticultural crops, as an intercrop with major crops. The importance of the use of organic and inorganic manure in tropical agriculture in increasing world food production has been thoroughly discussed (Aliyu and Olanrewaju, 1996).

The use of inorganic fertilizer is expensive for the resource poor farmers, besides the scarcity of the fertilizer. Results of studies carried out in Southwest of Nigeria emphasized agronomic potentials of livestock manures such as (cow, poultry) and oil palm sludge as soil amendments especially on acid soils in which inorganic $\mathrm{N}$ and $\mathrm{P}$ fertilizer may have adverse effect on soil by increasing its acidity. (Doran et al, 1996; Opara- Nadi et al, 2000). Animal wastes decompose and contribute organic matter, thereby increasing the overall fertility of the soil. Soil fertility has been the limiting factors in development of sustainable tropical agriculture (Mbagwu and Ekwealor, 1990). 
Thus, in this study, effort was made to evaluate and compare the economic viability of the effect of different types and levels of manure on tomato. It is expected that the study will advance knowledge on the use of locally available, affordable and environmentally friendly organic waste for enhancing the profitability of tomato production.

\section{METHODOLOGY}

Two field experiments were carried out during 2003 and 2004 cropping seasons (early and late) on loamy soils with tomatoes (Lycopersium esculentum . mill) at the Federal college of Agriculture and Edu village all in Akure, to evaluate the economic viability of application of livestock manure on tomato. The first experiment (2003) compared $100 \mathrm{Kg} \mathrm{ha}^{-1} \mathrm{~N}-\mathrm{P}-\mathrm{K}(20-10-10), 25 \mathrm{tha}^{-1}$ of cattle, goat, pig and poultry and amended (control) plot.

The second experiment (2004) compared five levels of poultry and goat manures $\left(0,10,25,40\right.$ and $\left.50 \mathrm{tha}^{-1}\right)$ in 2004 separately. The experimental design used was randomized complete blocks with three replications. Each plot measured $5 \times 5 \mathrm{~m}\left(25 \mathrm{~m}^{2}\right)$, the tomato was spaced out at $75 \times 50 \mathrm{~cm}$ to give a population density of 26,666 plants per hectare.

Tomato variety (Roma VF), which is vigorous, determinate, disease resistance variety and widely grown in Akure area was used. The seeds were nursed for 21 days (Bernary, 1995) and transplanted in the evenings at 4-6 leaf stage (10-12 cm tall). The treatment was applied on soil surface beside each plant two weeks after transplanting. One meter splitted bamboo stems were used as stake and twine was used to tie the tomato loosely to the stakes at an interval of $30 \mathrm{~cm}$. Manual weeding was done twice and thrice for early and late season crops respectively at three week interval after manure application.

Data were collected on plot basis and ten tomato stands were selected from the middle of each plot for this purpose. Harvesting was carried out at five days interval. The yield was determined with a salter scale.

Gross margin analysis was used to determine the economic viability.

$\mathrm{GM}=\mathrm{TR}-\mathrm{TVC}$

Where

$\mathrm{GM}=$ Gross Margin

$\mathrm{TR}=$ Value of farm output

$\mathrm{TVC}=$ Total variable cost

\section{RESULTS AND DISCUSSION}

The gross margin measures the contribution of that enterprise to the farm total profit. Given the fixed costs on a farm, the larger the total gross margin from all the enterprises on the farm, the larger the farm profit. The relative economic performance of each of the treatments was gauged by calculating the gross margin.In this study, there is an array of level of treatments to select, and the levels was ranked in order of magnitude of their gross margins i.e the higher the magnitude of gross margin, the better the treatment.

Table 1 shows the breakdown of the expenses from each of the treatment and tables 2,3 and 4 present the gross margin of the use of manures. The gross margin variability was lowest with cattle manure (Table 2). The economic analysis also revealed that poultry 


\section{Journal of Agriculture and Social Research (JASR) Vol. 8, No. 2, 2008}

manure would guarantee more profit, followed by goat. The exception was at Edu during the early season, where NPK had highest gross margin of N58,000.00. The higher gross margin recorded for poultry and goat in this work could be due to their lower $\mathrm{C}$ : $\mathrm{N}$ ratio when compared with the other manures. It could also be due to the supply of more nutrients than NPK fertilizer. Wang et al (1999) observed that addition of manure compost to the soil increased total organic matter, macro-nutrients $(\mathrm{N}, \mathrm{P}, \mathrm{Mg}, \mathrm{Ca}$ and $\mathrm{K})$ and micro nutrient ( $\mathrm{Cu}, \mathrm{Zn}$ and $\mathrm{Mn}$ ).

Compared to Edu, FECA was more profitable for late season. Thus soil structure and fertility of FECA could be better than that of Edu before the application of manures. As expected, the late crop was more profitable in all the cases for both sites than the early crop because tomato tends to perform better with less rainfall and more sunshine.Poultry and goat manures applied separately were generally more profitable at 25 tha $^{-1}$ (Table 3 and 4) and beyond this dosage gross margin decline. This could be due to the excessiveness of $\mathrm{N}$ in the soil, which favours vegetative growth to the detriment of fruiting. However, the highest gross margin was obtained in FECA at 40tha ${ }^{-1}$ during the early season. This trend was further reinforced by tables 5 to 7 where percent increase in gross margin due to usage of livestock manure on tomato was displayed.

\section{CONCLUSION}

Based on economic indicators, it pays better to apply poultry and goat manure to tomato because both will guarantee higher returns (Gross margin) when compared with the application of other manures. The optimum results could be obtained by applying 25 tha $^{-1}$ on tomato

\section{REFERENCES}

Adekiya and Ojeniyi (2002): Evaluation of Tomato growth and Soil Properties under different methods of seedling bed preparation in an Alfisol in the rain forest zone of South-west Nigeria. Soil Tillage Research, 64:275-279.

Aliyu L. and Olarewaju J.D., (1996): Response of pepper to fertilizers. Nutrient concentrations and uptake as affected by Nitrogen and Phosphorus levels. In the proceeding of the 14th HORTSON Conference, Ago Iwoye 1st - 4th April, 1996.

Doran J.W., Sarrantonio, M. and Liebio M.A., (1996): Soil health and sustainability. Advances in Agronomy 54:42-45.

F.A.O. (1993): Food and Agricultural Organisation of the United Nations, year book of production. Rome $254 \mathrm{Pp}$.

Mbagwu, J.S.C. and Ewealor, G.C., (1990): Agronomic potential of brewers spent grain. Biological wastes, 34:335-347.

Opara-Naid O.A., Omenihu, A.A. and Efemedebe, S.N., (2000): Effects of Organic wastes, fertilizer and mulch on productivity of an Ultisol. Proceedings of 26th Annual Conference of Soil Science Society of Nigeria, Ibadan, Ed. O. Babalola. Pp. 112-120 
Journal of Agriculture and Social Research (JASR) Vol. 8, No. 2, 2008

Table 1: Expenses incurred under various application of inorganic and organic manure of tomato

\begin{tabular}{|l|l|l|l|l|l|l|}
\hline & Control & Poultry & NPK & Cattle & Goat & Pig \\
\hline Fertilizer & - & - & 2075 & - & - & - \\
\hline Ploughing & 2500 & 2500 & 2500 & 2500 & 2500 & 2500 \\
\hline Fuel & 1625 & 1625 & 1625 & 1625 & 1625 & 1625 \\
\hline Harrowing & 2500 & 2500 & 2500 & 2500 & 2500 & 2500 \\
\hline Weeding & 37500 & 37500 & 37500 & 37500 & 37500 & 37500 \\
\hline Transportation & - & 12,500 & 12,500 & 12,500 & 12,500 & 12,500 \\
\hline Fertilizer App & - & 5000 & 5000 & 5000 & 5000 & 5000 \\
\hline $\begin{array}{l}\text { Splitting of } \\
\text { Bamboo }\end{array}$ & 26000 & 26000 & 26000 & 26000 & 26000 & 26000 \\
\hline Harvesting & 5000 & 5000 & 5000 & 5000 & 5000 & 5000 \\
\hline
\end{tabular}

Table 2: Gross margin of use of organic and inorganic manure on tomato

\begin{tabular}{|lrrrr|}
\hline Treatment & \multicolumn{1}{l}{ Early } & \multicolumn{1}{c}{ Season } & \multicolumn{1}{l}{ Late } & \multicolumn{1}{c|}{ Season } \\
& \multicolumn{1}{l}{ FECA } & \multicolumn{1}{l}{ EDU } & \multicolumn{1}{l}{ FECA } & \multicolumn{1}{c|}{ EDU } \\
\hline Control & & & & \\
Revenue & $107,000.00$ & $121,000.00$ & $121,250.00$ & $167,500.00$ \\
Expenses & $75,125.00$ & $75,125.00$ & $75,125.00$ & $75,125.00$ \\
Gross margin & $31,875.00$ & $45,875.00$ & $46,125.00$ & $92,375.00$ \\
NPK & & & & \\
Revenue & $139,000.00$ & $151,000.00$ & $146,250.00$ & $218,750.00$ \\
Expenses & $92,200.00$ & $92,200.00$ & $92,200.00$ & $92,200.00$ \\
Gross margin & $42,800.00$ & $58,800.00$ & $56,125.00$ & $126,550.00$ \\
Cattle manure & & & & \\
Revenue & $127,000.00$ & $137,000.00$ & $148,750.00$ & $158,750.00$ \\
Expenses & $92,625.00$ & $92,625.00$ & $92,625.00$ & $92,625.00$ \\
Gross margin & $34,375.00$ & $44,375.00$ & $56,125.00$ & $66,125.00$ \\
Goat manure & & & & \\
Revenue & $155,000.00$ & $144,000.00$ & $225,000.00$ & $226,250.00$ \\
Expenses & $92,625.00$ & $92,625.00$ & $92,625.00$ & $92,625.00$ \\
Gross margin & $62,375.00$ & $51,375.00$ & $132,350.00$ & $173,625.00$ \\
Pig manure & & & & \\
Revenue & $140,000.00$ & $136,000.00$ & $166,250.00$ & $308,000.00$ \\
Expenses & $92,625.00$ & $92,625.00$ & $92,625.00$ & $92,625.00$ \\
Gross margin & $47,375.00$ & $43,375.00$ & $73,625.00$ & $215,375.00$ \\
Poultry manure & & & & \\
Revenue & $167,000.00$ & $145,000.00$ & $267,500.00$ & $362,500.00$ \\
Expenses & $92,625.00$ & $92,625.00$ & $92,625.00$ & $92,625.00$ \\
Gross margin & $74,375.00$ & $52,375.00$ & $174,875.00$ & $269,875.00$ \\
\hline
\end{tabular}


Journal of Agriculture and Social Research (JASR) Vol. 8, No. 2, 2008

Table 3: Gross margin of use of different levels of poultry manure on tomato (N)

\begin{tabular}{|c|c|c|c|c|}
\hline Treatment & $\frac{\text { Early }}{\text { FECA }}$ & $\frac{\text { Season }}{\text { EDU }}$ & $\frac{\text { Late }}{\text { FECA }}$ & $\frac{\text { Season }}{\text { EDU }}$ \\
\hline \multicolumn{5}{|l|}{ ot ha ${ }^{-1}$} \\
\hline Revenue & $133,750.00$ & $85,000.00$ & $164,000.00$ & $189,000.00$ \\
\hline Expenses & $75,125.00$ & $75,125.00$ & $75,125.00$ & $75,125.00$ \\
\hline Gross margin & $58,625.00$ & $9,875.00$ & $88,875.00$ & 113875.00 \\
\hline \multicolumn{5}{|l|}{$10 \mathrm{ha}^{-1}$} \\
\hline Revenue & $192,500.00$ & $173,750.00$ & $271,000.00$ & $287,000.00$ \\
\hline Expenses & $92,625.00$ & $92,625.00$ & $92,625.00$ & $92,625.00$ \\
\hline Gross margin & $99,875.00$ & $81,125.00$ & $178,375.00$ & $194,375.00$ \\
\hline \multicolumn{5}{|l|}{$25 \mathrm{tha}^{-1}$} \\
\hline Revenue & $297,500.00$ & $253,750.00$ & $316,000.00$ & $397,000.00$ \\
\hline Expenses & $100,125.00$ & $100,125.00$ & $100,125.00$ & $100,125.00$ \\
\hline Gross margin & $197,375.00$ & $153,625.00$ & $215,875.00$ & $296,875.00$ \\
\hline \multicolumn{5}{|l|}{$40 \mathrm{ha}^{-1}$} \\
\hline Revenue & $213,750.00$ & $126,250.00$ & $227,000.00$ & $260,000.00$ \\
\hline Expenses & $107,625.00$ & $107,625.00$ & $107,625.00$ & $107,625.00$ \\
\hline Gross margin & $106,125.00$ & $18,625.00$ & $119,375.00$ & $152,375.00$ \\
\hline \multicolumn{5}{|l|}{$50 t \mathrm{ha}^{-1}$} \\
\hline Revenue & $140,000.00$ & $136,000.00$ & $166,250.00$ & $308,000.00$ \\
\hline Expenses & $92,625.00$ & $92,625.00$ & $92,625.00$ & $92,625.00$ \\
\hline Gross margin & $47,375.00$ & $43,375.00$ & $73,625.00$ & $215,375.00$ \\
\hline
\end{tabular}


Journal of Agriculture and Social Research (JASR) Vol. 8, No. 2, 2008

Table 4: Gross margin of use of different levels of goat manure on tomato (N)

\begin{tabular}{|c|c|c|c|c|}
\hline Treatment & $\begin{array}{l}\text { Early } \\
\text { FECA }\end{array}$ & $\frac{\text { Season }}{\text { EDU }}$ & $\begin{array}{l}\text { Late } \\
\text { FECA }\end{array}$ & $\frac{\text { Season }}{\text { EDU }}$ \\
\hline \multicolumn{5}{|l|}{ ot ha ${ }^{-1}$} \\
\hline Revenue & $181,250.00$ & $195,000.00$ & $145,000.00$ & $107,000.00$ \\
\hline Expenses & $75,125.00$ & $75,125.00$ & $75,125.00$ & $75,125.00$ \\
\hline Gross margin & $105,125.00$ & $119,875.00$ & $69,875.00$ & $31,875.00$ \\
\hline \multicolumn{5}{|l|}{ 10t ha $\mathrm{ha}^{-1}$} \\
\hline Revenue & $232,500.00$ & $260,000.00$ & $185,000.00$ & $157,000.00$ \\
\hline Expenses & $92,625.00$ & $92,625.00$ & $92,625.00$ & $92,625.00$ \\
\hline Gross margin & $139,875.00$ & $67,375.00$ & $92,375.00$ & $64,375.00$ \\
\hline \multicolumn{5}{|l|}{$25 \mathrm{ha}^{-1}$} \\
\hline Revenue & $255,000.00$ & $253,750.00$ & $316,000.00$ & $397,000.00$ \\
\hline Expenses & $100,000.00$ & $100,125.00$ & $100,125.00$ & $100,125.00$ \\
\hline Gross margin & $54,875.00$ & $237,375.00$ & $180,875.00$ & $131,875.00$ \\
\hline \multicolumn{5}{|l|}{$40 t \mathrm{ha}^{-1}$} \\
\hline Revenue & $336,250.00$ & $271,250.00$ & $269,000.00$ & $215,000.00$ \\
\hline Expenses & $107,625.00$ & $107,625.00$ & $107,625.00$ & $107,625.00$ \\
\hline Gross margin & $228,625.00$ & $163,625.00$ & $161,375.00$ & $107,375.00$ \\
\hline \multicolumn{5}{|l|}{$50 t$ ha $^{-1}$} \\
\hline Revenue & $333,750.00$ & $223,750.00$ & $258,000.00$ & $202,000.00$ \\
\hline Expenses & $112,625.00$ & $112,625.00$ & $112,625.00$ & $112,625.00$ \\
\hline Gross margin & $221,125.00$ & $111,125.00$ & $145,375.00$ & $89,375.00$ \\
\hline
\end{tabular}

Table 5: Percent increase in gross margin due to the usage of livestock manures on tomato $(2000)$

\begin{tabular}{lllll}
\hline Treatments & Early & Season & \multicolumn{2}{c}{ Late Season } \\
\cline { 2 - 5 } & FECA & EDU & FECA & EDU \\
\hline NPK & 147 & 128 & 117 & 137 \\
Cattle & 108 & 97 & 122 & 72 \\
Goat & 196 & 112 & 287 & 188 \\
Pig & 149 & 96 & 160 & 233 \\
Poultry & 233 & 114 & 379 & 292 \\
\hline
\end{tabular}

Table 6: Percent increase in gross margin due to the usage of different levels of poultry manures on tomato (2001)

\begin{tabular}{lllll}
\hline $\begin{array}{l}\text { Treatments } \\
\left(\mathrm{t} \mathrm{ha}^{-1}\right)\end{array}$ & Early & Season & \multicolumn{2}{c}{ Late Season } \\
\cline { 2 - 5 } & FECA & EDU & FECA & EDU \\
\hline 10 & 170 & 822 & 201 & 170 \\
45 & 337 & 155 & 243 & 260 \\
40 & 181 & 188 & 134 & 134 \\
\hline
\end{tabular}


Journal of Agriculture and Social Research (JASR) Vol. 8, No. 2, 2008

\begin{tabular}{lllll}
\hline 50 & 149 & 201 & 113 & 119
\end{tabular}

Table 7: Percent increase in gross margin due to the usage of different levels of goat manure on tomato (2002)

\begin{tabular}{lllll}
\hline $\begin{array}{l}\text { Treatments } \\
\left(\mathrm{t} \mathrm{ha}^{-1}\right)\end{array}$ & Early & Season & \multicolumn{2}{c}{ Late Season } \\
\cline { 2 - 5 } & FECA & EDU & FECA & EDU \\
\hline 10 & 133 & 132 & 132 & 202 \\
25 & 147 & 198 & 259 & 414 \\
40 & 217 & 136 & 231 & 337 \\
50 & 210 & 93 & 208 & 280 \\
\hline
\end{tabular}

